Towards Achieving Sustainability in Financial Market: The Impact of Covid-19, Oil Price, Stock Price on Exchange Rate Volatility in Indonesia

Rossanto Dwi Handoyo, Syekha Maulana llyas, Abdul Rahim Ridzuan, Nur Azirah Zahida Mohamad Azhar, Mohd Shahidan Shaari

To Link this Article: http://dx.doi.org/10.6007/IJARBSS/v11-i5/9764

DOI:10.6007/IJARBSS/v11-i5/9764

Received: 07 March 2021, Revised: 10 April 2021, Accepted: 02 April 2021

Published Online: 27 May 2021

In-Text Citation: (Handoyo et al., 2021)

To Cite this Article: Handoyo, R. D., Ilyas, S. M., Ridzuan, A. R., Azhar, N. A. Z. M., \& Shaari, M. S. (2021).

Towards Achieving Sustainability in Financial Market: The Impact of Covid-19, Oil Price, Stock Price on

Exchange Rate Volatility in Indonesia. International Journal of Academic Research in Business and Social

Sciences, 11(5), 842-863.

Copyright: (c) 2021 The Author(s)

Published by Human Resource Management Academic Research Society (www.hrmars.com)

This article is published under the Creative Commons Attribution (CC BY 4.0) license. Anyone may reproduce, distribute, translate and create derivative works of this article (for both commercial and non-commercial purposes), subject to full attribution to the original publication and authors. The full terms of this license may be seen

at: http://creativecommons.org/licences/by/4.0/legalcode

Vol. 11, No. 5, 2021, Pg. 842 - 863

http://hrmars.com/index.php/pages/detail/IJARBSS

JOURNAL HOMEPAGE

Full Terms \& Conditions of access and use can be found at http://hrmars.com/index.php/pages/detail/publication-ethics 


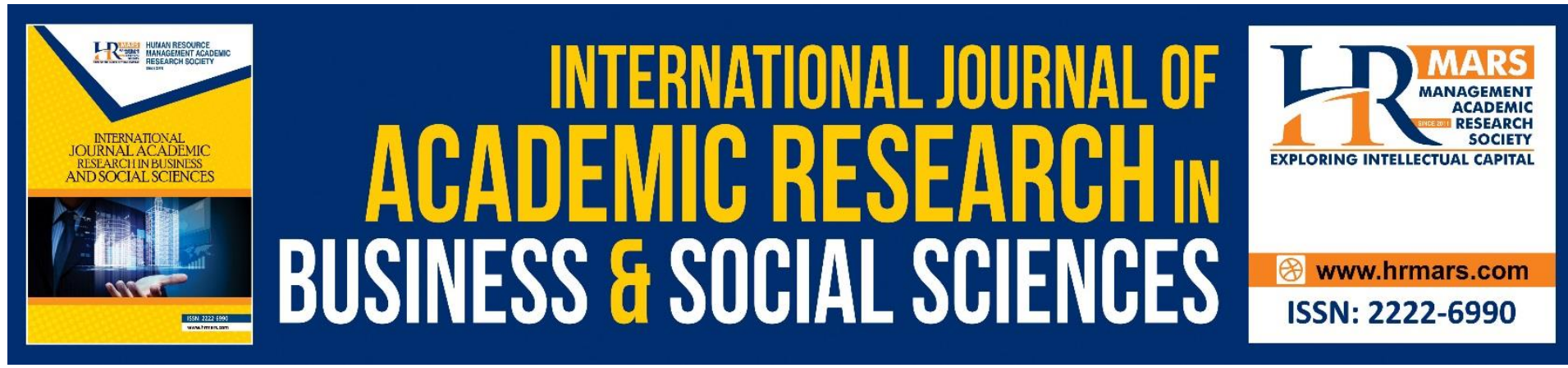

\title{
Towards Achieving Sustainability in Financial Market: The Impact of Covid-19, Oil Price, Stock Price on Exchange Rate Volatility in Indonesia
}

\author{
Rossanto Dwi Handoyo a, Syekha Maulana llyas ${ }^{a}$, Abdul Rahim \\ Ridzuan ${ }^{\text {11 }}$, Nur Azirah Zahida Mohamad Azharc, Mohd \\ Shahidan Shaarid \\ ${ }^{a}$ Faculty of Economics and Business, Airlangga University, Indonesia, ${ }^{b}$ Faculty of Business \\ and Management, Universiti Teknologi MARA, Melaka, 'Faculty of Business and \\ Management, Universiti Teknologi MARA, Selangor, ${ }^{\mathrm{d}}$ Faculty of Applied and Human \\ Sciences, Universiti Malaysia Perlis, Malaysia
}

\begin{abstract}
The spread of the Corona Virus Disease pandemic (COVID-19) is so fast that it poses a health threat and an economic crisis. Since the beginning of March, COVID-19 has spread in Indonesia. Some economic elements, such as the exchange rate, share prices, and so on, have been quite turbulent. This study analyzes the effect of Corona Virus Disease variable (COVID19), as well as national stock price variables, world oil price variables and exchange rates of countries in ASEAN on IDR / USD exchange rate volatility in the long term and short term. The approach used is a quantitative analysis with the ARDL method and using the ARCH / GARCH method to calculate exchange rate volatility. Estimation results in the selected model show that national stock prices, COVID-19, and world oil prices have a significant effect. Both have a negative correlation with exchange rate volatility in the long run. In the short term, only the national stock price variable does not affect the exchange rate volatility. In contrast, the COVID-19 variable and world oil prices have a significant effect, and each is positively and negatively related to exchange rate volatility. Estimation results show that the exchange rates of countries in ASEAN affected exchange rate volatility during the COVID-19 Pandemic.
\end{abstract}

Keywords: Exchange Rate Volatility, ARCH / GARCH, COVID-19

Introduction

The World Health Organization (WHO) issued a global warning about deadly infectious diseases that began in December 2019 in Wuhan, China (Maclntyre, 2020). On February 11, 2020, WHO named the disease Corona Virus Disease (COVID-19) caused by the Severe Acute Respiratory Syndrome Corona Virus-2 (SARS-CoV-2) virus (WHO, 2020a). The first COVID-19 case was in December 2019, in Wuhan, Hubei Province, China, with reports of mysterious cases of Pneumonia, precisely on 18 to December 19, 2019, there were five patients treated

${ }^{1}$ Corresponding author: Rahim670@uitm.edu.my 
with the diagnosis of Acute Respiratory Distress Syndrome (ADRS) (Ren, 2020). The spread of the disease is out of control; in its development on March 30, 2020, there were 693,224 cases and 33,106 deaths worldwide, including Indonesia, which has the highest mortality rate in Southeast Asia with 8.9\% (WHO, 2020b).

$3,000 \mathrm{k}$

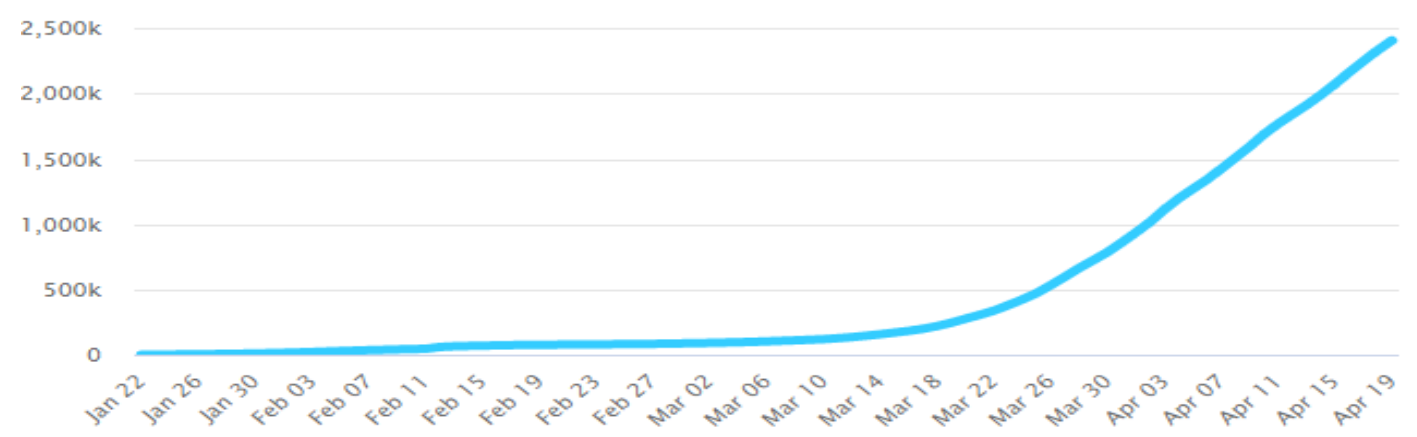

Source: Worldometer (2020).

Figure 1. Total Cases of COVID-19 in the World (March 2, 2020 - April 19, 2020)

Figure 1 displays data on the development of COVID-19 cases globally, with an upward trend, signifying the rapid and widespread spread of COVID-19. In early March, to be exact on March 2, 2020, Indonesia announced a Corona Virus case for the first time, which two people are found as positive. Previously, on February 14, 2020, both of them attended a dance class attended by more than 12 people at a restaurant in Kemang, West Java. This case began with a report from the Malaysian Government, which reported that one of the dance class participants from Japan was positive about having the Corona Virus when getting tested in Malaysia. Since then, Corona Virus cases in Indonesia have continued to increase, as shown in Figure 2. On March 8, 2020, a total of 6 people who attended the dance class were reported to be positively infected by Corona Virus and began to spread to various regions in Indonesia. As of March 31, 2020, a total of 1,528 cases were confirmed in Indonesia with 136 deaths (Ministry of Health of the Republic of Indonesia, 2020).

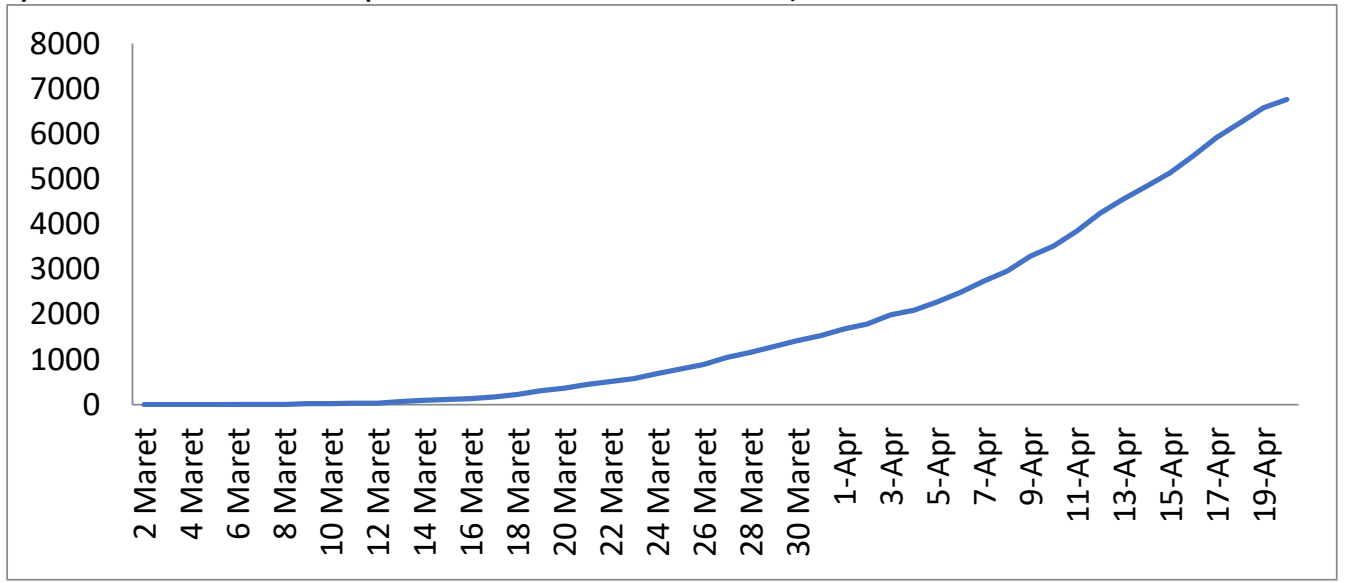

Source: Indonesian Ministry of Health (2020).

Figure 2. Total Cases of COVID-19 in Indonesia (March 2 - April 19, 2020).

Based on information from the World Health Organization (2020c), the spread of the SARS-CoV-2 virus is transmitted through, among others, liquid droplets, fomites (inanimate objects), and close contact with their spread through feces, not airborne. Most countries carry out social restriction policies, which means creating physical distance between individuals and 
carrying out appropriate health protocol, to strengthen each individual's antibody in the face of Covid-19. China has carried out a lockdown policy to break the chain of the spread of SARSCoV-2 in Wuhan, which became the ground zero spread of this virus. However, not all countries dare to apply Lockdown policy because it will lead to greater instability for the country's economy. The shock effect of the acceleration of the spread of Covid-19 made the weakening of the global economy and several countries on the verge of recession. Pandemics have a real impact on global economic growth. Congressional Research Service - Jackson (2020) estimates that the virus has slashed global economic growth by at least $0.5 \%$ to $1.5 \%$, but its full impact will not be known until its effects peak.

Corona Virus, the main one, is a threat to public health, but its spread is so fast and will have an impact on the economy if it is not being handled properly. The outbreak called Covid-19 will trigger a recession in several countries and slow down global annual growth to below 2.5\% (UNTCAD, 2020). An increasing number of Covid-19 cases cause economic gridlock in almost the entire world. The restaurant industry stopped, so did the aviation industry, car manufacturing, hotels, gyms, and shipping lines. The stagnation in economic activity has caused public consumption to decline, and this has resulted in a severed termination of employment (PHK) across the country (Stewart, 2020). Adverse economic impacts for other countries are very significant due to disruptions in the global supply chain, decreased demand for imported goods and services, and a decline in international tourism and business travel (Refk, 2020).

The United Nations Conference on Trade and Development - UNTCAD (2020) explains that the duration and level of risk of crises caused by this Pandemic depend on three variables, namely: How far and quickly the virus spreads, how long before the vaccine is found, and the effectiveness of policies implemented in reducing risk health and economy of a country. Uncertainty in each of these variables affects the level of anxiety of people, which will also impact the level of risk of the crisis that will occur. One of the variables that affect the stock market volatility is quite severe, because of public panic as shown in Figure 3.

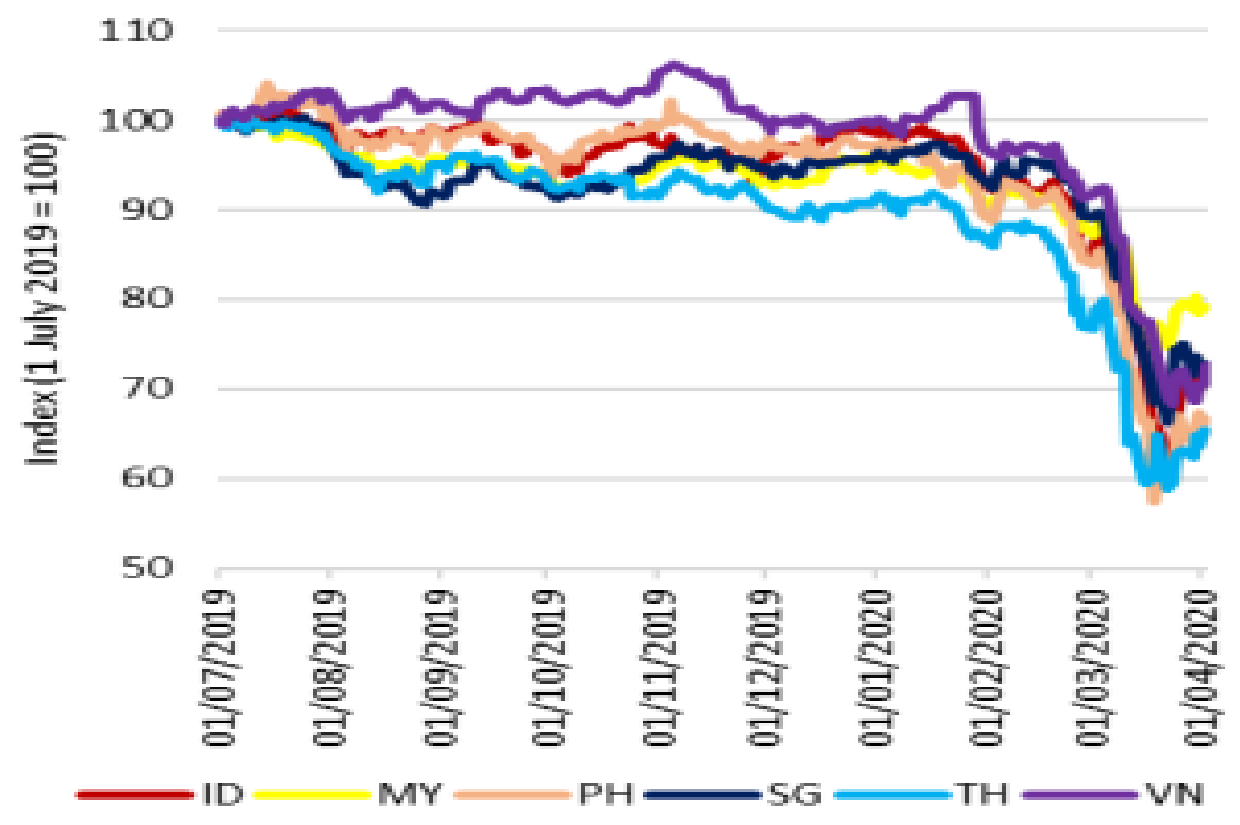

Source: ASEAN Development Bank (2020)

Figure 3. ASEAN Capital Market Index During the COVID-19 Pandemic 
Figure 3. explains the stock market conditions in ASEAN countries in the early days of the Corona Virus spread by showing a capital market index. As can be seen from the figure, most of the stock indexes in ASEAN countries have declined sharply. This decline was triggered by panic over the influence of global markets. The impact of the virus on the stock market, in turn, will have an impact on global growth. Since the beginning of March 2020, there is a sharp decline in the Indonesian stock market because of falling global stocks, which have been hit by investor concerns over the economic impact of the increasingly widespread Corona Virus. At the same time, exchange rate movements also experience unusual things.

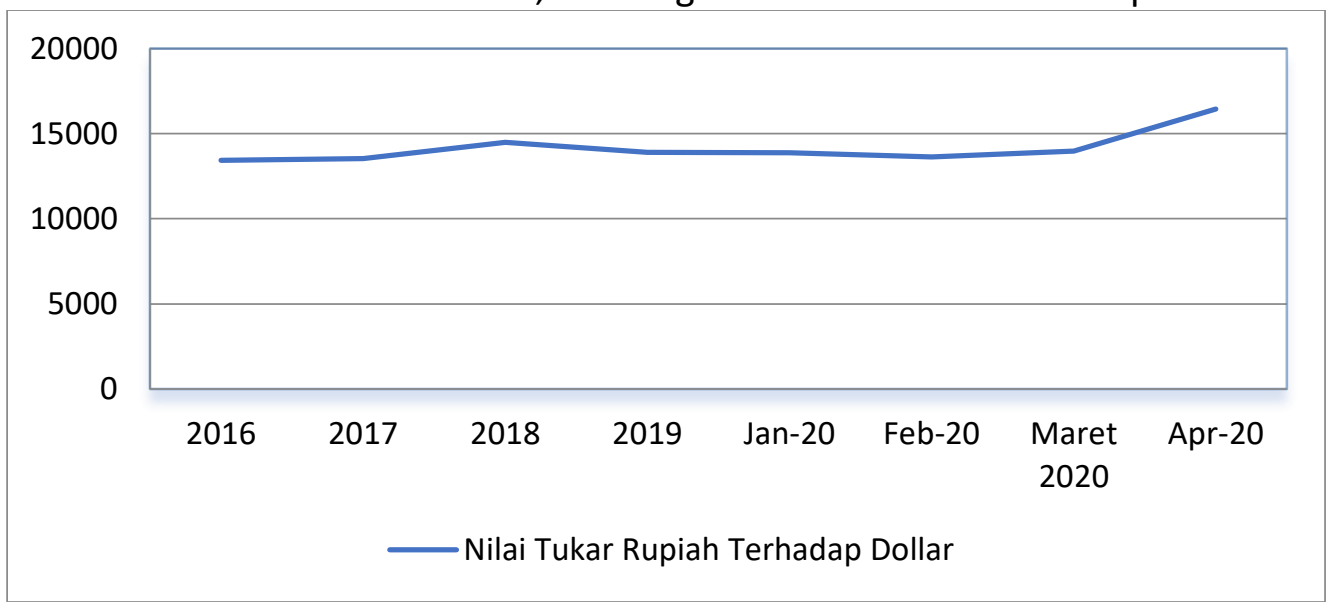

Source: Bank Indonesia (2020).

Figure 4. Rupiah exchange rate against US Dollar 2016 - 2020

Figure 4 above shows the rupiah exchange rate depreciated quite sharply in March late 2020. The exchange rate of the last five years was constant at around 13,000 US Dollars, then experienced unexpected volatility, which depreciated, reaching 16,449 in April 2020. This is a series of impacts from Corona Virus, which caused an increase in public anxiety and the US Federal Reserve reducing interest rates and buying bonds. When the Central Bank of each country could not follow the Fed's policies, the US dollar will likely weaken the exchange rates of some countries. Such conditions are similar to the 2007-2009 financial crisis. The dollar has emerged as the currency of choice by investors as a haven, given its role as the dominant global reserve currency. Not only in Indonesia, where the exchange rate has fluctuated quite sharply, most countries in the world, especially developing countries such as the ASEAN countries, also experienced depreciation during the Pandemic.

Several previous studies have discussed the Corona Virus's effects on macroeconomic conditions in the real sector (e.g., Barro, 2020; Estrada, 2020; Kohlscheen, 2020; McKibbin, 2020). Little research has been found linking the impact of COVID-19 on the exchange rate (e.g., Cardona-Arenas, 2020; Villarreal-Samaniego, 2020). Most previous studies explained the factors that influence the exchange rate volatility of macroeconomic variables (Mirchandani, 2013; Giannellis, 2015; Nor, 2020).

The novelties in this study are first to analyze the volatility of the IDR / USD exchange rate due to the rapid spread of COVID-19 infectious diseases by adding variable national stock prices and world oil prices that have been volatile during the Pandemic. Secondly, this study also analyzes the effect of exchange rates in ASEAN countries on the volatility of the IDR / USD exchange rate.

Exchange rate volatility is an essential thing for every country because it will directly or indirectly impact the price of essential commodities (Krugman, 2007). Exchange rate 
volatility or exchange rates can be interpreted by the magnitude of the fluctuation distance or the difference between the exchange rate or exchange rate. Various literature has explained the factors that affect exchange rate volatility, such as price levels, economic growth, fiscal and economic policies, or non-economic factors (Twarowska, 2014). For example, Giannellis's research (2015) explained that interest rates, industrial production indices, and national stock prices influence exchange rates. In addition to endogenous factors, there are external factors that influence exchange rate volatility, such as world oil prices and world interest rates that significantly influence exchange rate volatility (Kutu, 2016). Villarreal-Samaniego (2020) also explained the non-economic factors using the COVID-19 variable, and the results explain that COVID-19 affects the exchange rate movements. The exchange rate is a reflection of the condition of the foreign exchange market that illustrates economic fundamentals. In certain conditions, the exchange rate is very volatile, and this is related to the expectations of market participants that change depending on the situation. When there are global issues or bad news about the world economy or country, it will cause concern and panic in market participants (Bouoiyour, 2020). A high or low level of market panic depends on the credibility of a country's Government in taking fiscal and monetary policies to keep things stable. If the credibility of the policy given is seen as low, then market participants will flee their capital abroad to seek safe haven. The impact is that the exchange rate left by market participants depreciates and has a propagating effect on the others.

This study uses the Autoregressive Conditional Heteroscedasticity / Generalized Autoregressive Conditional Heteroscedasticity (ARCH / GARCH) model in calculating the volatility of the Rupiah against the US Dollar during the Pandemic. To examine the short-term and long-term relationship between the volatility of the IDR / USD exchange rate with the Covid-19 pandemic variable, world oil prices and the exchange rates of ASEAN countries, this study uses the Autoregressive Distributed Lag (ARDL) model proposed by (Pesaran, Shin, and Smith, 2001).

\section{Literature Review}

The health crisis due to COVID-19 affected the global economy, like the SARS outbreak in 2002, which impacted the pace of investment in Asia and had a domino effect on each regional economy (Lee, 2004). Cases of infectious diseases have occurred several times, including Spanish Flu, SARS, Ebola, HIV, MERS, and others. Many studies have discussed the impact of the health crisis on the economy. Hai (2004) explains the short-term impact of SARS, which has sizable losses on China's tourism industry. Likewise, in Hong Kong, SARS has a negative impact, especially on the demand side, the tourism sector and the aviation industry (Siu, 2004). Of course, the health crisis that hit due to COVID-19 caused public panic and uncertainty of the global economy, the most striking can be seen in the exchange rate volatility, stock prices, and world oil prices. Kutu (2016) analyzed the impact of the global shock on the Russian exchange rate (Rubbel / US Dollar), using the GARCH and APARCH models to produce a significant negative effect of global shock, as seen from oil prices and world interest rates, on the Rubbel exchange rate against the dollar.

Like other infectious diseases, Corona Virus also has a significant domino effect on the global economy. Estrada (2020) in his research "The Economic Impact of Massive Infectious and Contagious Diseases: The Case of Wuhan Corona Virus" using the development of a new model namely the IMICDE-Simulator (The Massive Integral Infections and Contagious Diseases of the Economic Simulator), shows that the Corona Virus will have a significant negative economic impact on the Chinese economy. The results of the research simulation 
show that China's economic growth will decline from 6.2\% to 4.3\% between 2019 and 2020 . Corona Virus also affects East and Southeast Asia's economic growth because these economies are closely related to the Chinese economy. Besides, Albulescu (2020) examined the impact of Corona Virus and oil prices using the Autoregressive Distributed Lag (ARDL) model, which results in global shock due to COVID-19 also having a negative impact on world oil prices (Albulescu, 2020; Maijama et al., 2020). Shocks to global variables then have a negative impact on each country's macroeconomic fundamentals, such as exchange rates and national stock prices that influence each other (Choo, 2002; Mao, 2013; Manasseh, 2019).

More clearly, Cardona-Arenas (2020), in his research, explained the impact of Covid19 and world oil prices on the Colombian peso exchange rate. Using the VAR model, the results show that from March 6, 2020, when the first positive Covid-19 case was diagnosed in Colombia, the depreciation of the Colombian currency against the US dollar, began. This, in turn, happened because of the decline in international oil prices. The sharp exchange rate volatility of each country is due to public panic over its assets, thus diverting to haven. One of the havens is bitcoin, seen from the price level that rose high in this period, which was previously in a stagnant position (Bouoiyour, 2020). Research on the impact of Covid-19 has been carried out, but most of it looks at the macroeconomic side, especially in the industrial sector and mostly in developed countries.

In contrast, developing countries that were greatly affected by the uncertainty of this crisis triggered cash outflows in most developing countries and resulted in high exchange rate volatility. The volatility of the exchange rate in the global Pandemic has been less analyzed, even though the exchange rate position has an essential role in the economy. The importance of exchange rate volatility on the economy, so that the variables that influence it are interesting to study.

In his research, Villareal-Samaniego (2020) analyzed the long-term and short-term relationship between the exchange rate movements of the three currencies of the exporting country and the two oil-importing countries with the variable COVID-19 and the price of crude oil. Estimation results using the ARDL model show a significant relationship between exchange rate movements and COVID-19 in the currencies of two countries (Brazil Real and South African Rand), while changes in oil prices have a significant effect on the volatility of the exchange rates of the five countries, which both move downward (depreciated). Besides, Giannellis (2015), in his research, "What causes exchange rate volatility? Evidence from selected EMU members and candidates for EMU membership countries "using the VAR model and the GARCH model explains that interest rates affect exchange rates. In comparison, the national stock price affects the exchange rate indirectly, as a spillover effect of the interest rate. Some studies also explain the exchange rates of other countries, previous exchange rates, world interest rates, world oil prices, stock prices, and psychological factors that also influence exchange rate volatility (Pelinesu, 2014; Cetiner, 2018; Kutu, 2016).

In the case of Indonesia, several studies analyze the factors that influence exchange rate volatility. Rasbin (2015) examined the influence of macroeconomic, non-economic and news factors on the movement of the rupiah exchange rate for the period 2004-2014, and the results showed that in the previous exchange rate variable, interest rates, elections, economic growth news and news the price level significantly influenced movements exchange rate. Besides that, international trade factors, capital flows, interest rates, exchange rate expectations, foreign exchange reserves, and risk levels also affect the rupiah exchange rate (Simorangkir, 2004). Pressure on the exchange rate is not only influenced by fundamental factors but also triggered by market sentiment due to speculation and sudden large-scale 
currency transactions by market players as affirmed by Syarifuddin (2015). Fluctuations in stock prices and world oil prices also affect the movement of the Rupiah exchange rate (Bappepam-LK, 2008; Raraga, 2012; Nizar, 2012).

\section{Overview of Variables}

The COVID-19 Pandemic put severe pressure on the global and domestic economies, which simultaneously dropped both the demand and the supply sides dramatically. The economic uncertainty that occurred during the Pandemic caused negative sentiment in the market, resulting in unusual fluctuations in exchange rates and stock prices in most countries, especially in developing countries. Logical indeed, market participants' behavior to shift their capital to assets that are considered safe to reduce or avoid risks due to a pandemic. Bank Indonesia (2020) noted the adjustment of capital outflows from developing countries to safehaven assets such as gold and US Treasury Bonds. During the Pandemic, the Rupiah experienced high volatility and experienced a sharp depreciation over the past ten years, reaching Rp16,441 in early April 2020. Not only in Indonesia, but the exchange rates of ASEAN countries also experienced depreciation, as shown in Figure 5.

Based on the report of the Indonesian Ministry of Health (2020), the trend of new cases of COVID-19 continues to increase. The number of new cases every day provides information to market participants regarding the interrelation of the development of the COVID-19 case and the economic implications, given that financial markets are very volatile during the Pandemic. One side of the COVID-19 case is experiencing an upward trend. On the other hand, national stock prices and world oil prices are experiencing a downward trend amid uncertainty and falling global demand and supply.

The national stock price is a value of the Composite Stock Price Index (CSPI) used to measure shares listed on the Indonesia Stock Exchange (JKSE). This index covers the price movements of all stock and preferred shares listed on the IDX. The variable national stock price as an independent variable in this study is based on a sharp decrease in share prices simultaneously with a decrease in the exchange rate of IDR / USD. Meanwhile, world oil prices also declined sharply and even touched the US \$-33.1, global crude oil prices are formed from a balance between the demand and supply of world oil commodities so that when shocks occur on one side, it will cause disequilibrium. The world oil price is calculated in denominations of US dollars per barrel (1 barrel = 159 liters), using the average world oil price, one of which is used in this study using the West Texas Intermediate (WTI) reference. The period under consideration starts from January 23, 2020, with China's adoption of a lockdown policy that signals the decline in global demand and hampered economic activity during the Pandemic. 
INTERNATIONAL JOURNAL OF ACADEMIC RESEARCH IN BUSINESS AND SOCIAL SCIENCES Vol. 11, No. 5, 2021, E-ISSN: 2222-6990 ㄷ 2021 HRMARS
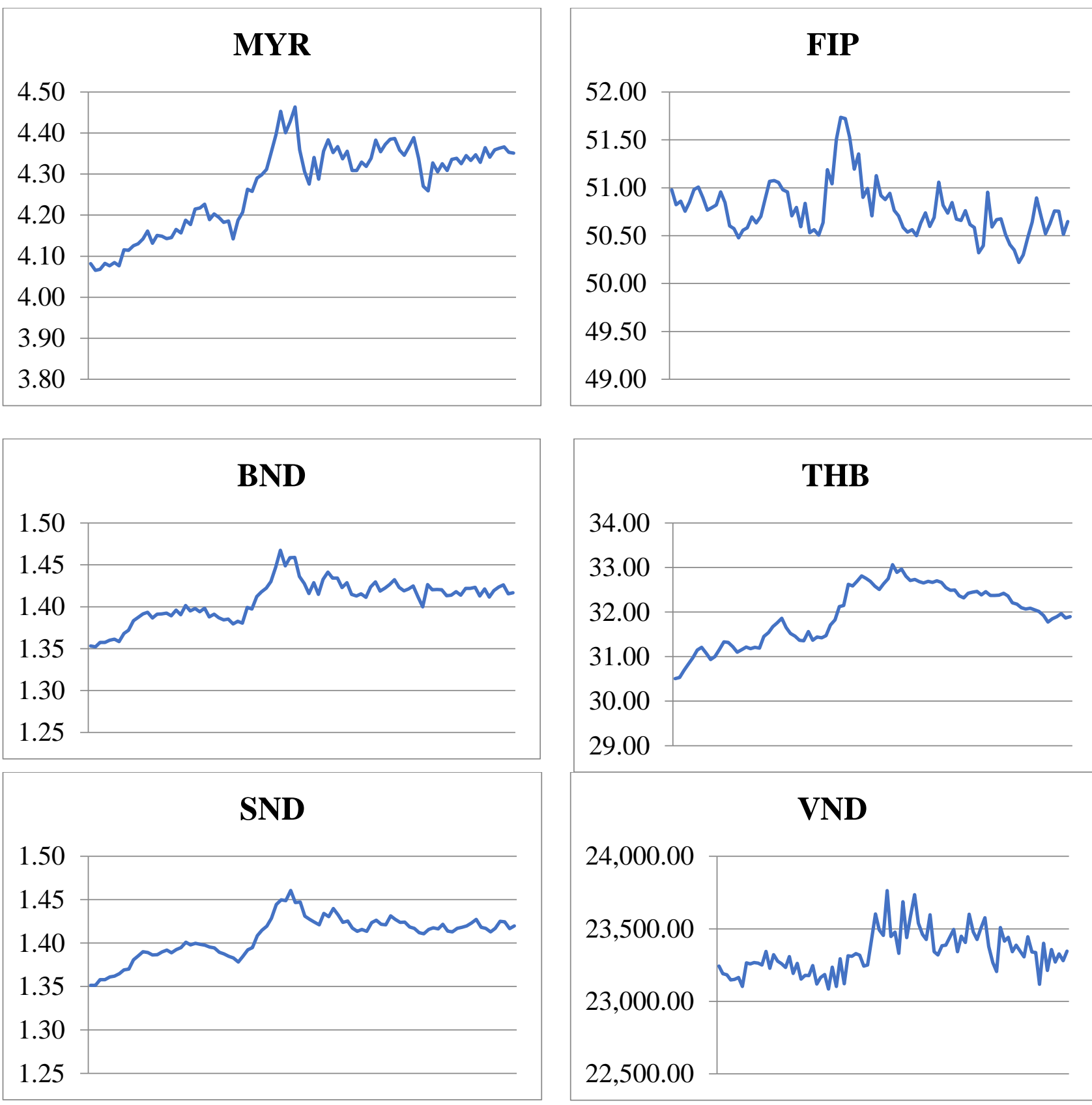

Note: exchange rate represents local currency against USD. (MYR represent Malaysia Ringgit, FIP for Filipina Peso, BND for Brunei Dollar, THB for Thailand Bhat, SND Singapore Dollar, and VND for Vietnam Dong). Source: Exchange-Rate.org

Figure 5. Exchange Rate of ASEAN Countries during Pandemic.

(January 23, 2020 - May 27, 2020)

\section{Data, Models, and Methodologies}

Data

The study uses daily time-series data from January 23, 2020 - May 27, 2020, with five working days, bringing a total of 90 observations. The following is a detailed explanation of the research variables in Table 1. 


\section{Table 1. Types and Sources of Data}

\begin{tabular}{|c|c|c|}
\hline Variables & Measurement Variables and Explanation & Data Sources \\
\hline $\begin{array}{l}\text { Exchange } \\
\text { Rates IDR / } \\
\text { USD (EX) }\end{array}$ & $\begin{array}{l}\text { Exchange rate data uses the } \\
\text { reference/reference exchange rate determined } \\
\text { by Bank Indonesia. The exchange rate data is } \\
\text { carried out the natural logarithmic } \\
\text { transformation process. Then, the ARCH / } \\
\text { GARCH process obtains the exchange rate } \\
\text { volatility value from the GARCH conditional } \\
\text { variance value. }\end{array}$ & www.bi.go.id \\
\hline $\begin{array}{l}\text { National Stock } \\
\text { Price (LSP) }\end{array}$ & $\begin{array}{l}\text { The national stock price data used is the opening } \\
\text { price data of the } \mathrm{JCl} \text {, and the natural logarithmic } \\
\text { transformation process is then performed. }\end{array}$ & $\begin{array}{l}\text { www.finance.yah } \\
\text { oo.com }\end{array}$ \\
\hline $\begin{array}{l}\text { Number of } \\
\text { new COVID } \\
\text { cases per day } \\
\text { (COVID) }\end{array}$ & $\begin{array}{l}\text { Data is taken from the total number of new } \\
\text { cases every day starting from March 2, } 2020 \text { to } \\
\text { May 27, 2020. Data is unitary without a } \\
\text { transformation process. }\end{array}$ & $\begin{array}{l}\text { www.kemkes.go. } \\
\text { id }\end{array}$ \\
\hline $\begin{array}{l}\text { World Oil } \\
\text { Prices (OPR) }\end{array}$ & $\begin{array}{l}\text { World oil price data uses the WTI price } \\
\text { reference, adjusted to the rupiah exchange rate. } \\
\text { The world oil price variable uses a ratio scale } \\
\text { after a natural logarithmic transformation } \\
\text { process is carried out. }\end{array}$ & www.eia.gov. \\
\hline $\begin{array}{l}\text { ASEAN } \\
\text { countries } \\
\text { 'exchange } \\
\text { rates against } \\
\text { the USD }\end{array}$ & $\begin{array}{l}\text { exchange rate ASEAN countries' data are } \\
\text { independent variables. The data is carried out in } \\
\text { a natural logarithm process, and their effects } \\
\text { are tested on the dependent variable in the } \\
\text { study. }\end{array}$ & $\begin{array}{l}\text { www.exchange- } \\
\text { rate.org }\end{array}$ \\
\hline
\end{tabular}

\section{Model}

The analysis model refers to the Villarreal-Samaniego study (2020), the ARCH / GARCH Model is used in calculating the volatility of the Rupiah exchange rate against the US Dollar during a pandemic and the Autoregressive Distributed Lag (ARDL) model is used to analyze the effect of national stock prices, COVID-19 and oil prices world to IDR / USD exchange rate volatility. Following are the ARCH / GARCH models and the Autoregressive Distributed Lag (ARDL), Model:

\section{Model ARCH/GARCH}

$$
\begin{array}{ll}
\mathrm{H}_{\mathrm{t}}=\mathrm{C}_{0}+\alpha_{2} \varepsilon^{2}{ }_{\mathrm{t}-1}+\alpha_{1} \mathrm{~h}_{\mathrm{t}-1}+\mu_{\mathrm{t}} \\
\mathrm{H}_{\mathrm{t}} \quad: \text { Conditional variance } \\
\mathrm{C}_{0} \quad: \text { Constanta } \\
\varepsilon^{2}{ }_{\mathrm{t}-1} & : \text { ARCH } \\
\mathrm{h}^{2}{ }_{\mathrm{t}-1} & : \text { GARCH }
\end{array}
$$




\section{Autoregressive Distributed Lag (ARDL) Model}

The basic model in the framework of the ARDL model in this study is based on the Error Correction Model (ECM), which considers long-term balance with short-term adjustments.

The specifications for the general equation of the ARDL model (Model 1), as follows:

VOLEX $_{\mathrm{t}}=\beta_{0}+\Sigma \beta_{1} \Delta$ VOLEX $_{\mathrm{t}-\mathrm{i}}+\Sigma \beta_{2} \Delta \mathrm{LSP}_{\mathrm{t}-\mathrm{i}}+\Sigma \beta_{3} \Delta$ COVID $_{\mathrm{t}-\mathrm{i}}+\Sigma \beta_{4} \Delta \mathrm{OPR}_{\mathrm{t}-\mathrm{i}}+\beta_{5 \mathrm{~L}} \mathrm{SP}_{\mathrm{t}-1}+\beta_{6}$ COVID $_{\mathrm{t}-1}+$ $\beta_{7} \mathrm{OPR}_{\mathrm{t}-1}+\delta \mathrm{ECT}_{-1} \varepsilon_{\mathrm{t}}$

Where:

VOLEX : Exchange rate volatility of the Rupiah against the US Dollar

LSP : Logarithm Natural national stock price.

COVID : The number of new cases of COVID-19 per day.

OPR : Changes in world oil prices.

$\beta_{1}, \beta_{2}, \beta_{3}, \beta_{4}$ : Short-term parameter

$\beta_{5}, \beta_{6}, \beta_{7} \quad$ : Long-term parameter

$\Delta \quad$ : first difference

$\mathrm{t} \quad$ : time-series data

The specifications for the general equation of the ARDL model (model 2), as follows:

VOLEX $_{\mathrm{t}}=\beta_{0}+\Sigma \beta_{1} \Delta$ VOLEX $_{\mathrm{t}-\mathrm{i}}+\Sigma \beta_{2} \Delta$ LBND $_{\mathrm{t}-\mathrm{i}}+\Sigma \beta_{3} \Delta$ LKAR $_{\mathrm{t}-\mathrm{i}}+\Sigma \beta_{4} \Delta$ LLAK $_{\mathrm{t}-\mathrm{i}}+\Sigma \beta_{5} \Delta$ LMYR $_{\mathrm{t}-\mathrm{i}}+$ $\Sigma \beta_{6} \Delta$ LMYK $_{\mathrm{t}-\mathrm{i}}+\Sigma \beta_{7} \Delta \mathrm{LFIP}_{\mathrm{t}-\mathrm{i}}+\Sigma \beta_{8} \Delta \mathrm{LSGD}_{\mathrm{t}-\mathrm{i}}+\Sigma \beta_{9} \Delta \mathrm{LTHB}_{\mathrm{t}-\mathrm{i}}+\Sigma \beta_{10} \Delta \mathrm{LVND}_{\mathrm{t}-\mathrm{i}}+\beta_{11} \mathrm{LBND}_{\mathrm{t}-}$ ${ }_{1}+\beta_{12}$ LKARt $-1_{\mathrm{t}}+\beta_{13}$ LAK $_{\mathrm{t}-1}+\beta_{14} \mathrm{LMYR}_{\mathrm{t}-1}+\beta_{15}$ LMYK $_{\mathrm{t}-1}+\beta_{16}$ LFIP $_{\mathrm{t}-1}+\beta_{17}$ LSGD $_{\mathrm{t}-1}+$ $\beta_{18} \mathrm{LTHB}_{\mathrm{t}-1}+\beta_{19} \mathrm{LVND} \mathrm{t}_{\mathrm{t}-1}+\delta \mathrm{ECT}_{-1}+\varepsilon_{\mathrm{t}}$

Where:

VOLEX : Exchange rate volatility Rupiah against Dollar AS

LBND : Logarithm Natural Brunei exchange rate BND/USD

LKAR : Logarithm Natural Cambodia exchange rate KAR/USD

LLAK : Logarithm Natural Laos exchange rate LAK/USD

LMYR : Logarithm Natural Malaysia exchange rate MYR/USD

LMYK : Logarithm Natural Myanmar exchange rate MYK/USD

LFIP : : Logarithm Natural Philippines exchange rate FIP/USD

LSGD : Logarithm Natural Singapore exchange rate SGD/USD

LTHB : Logarithm Natural Thailand exchange rate THB/USD

LVND : Logarithm Natural Vietnam exchange rate VND/USD

$\beta_{1-} \beta_{10}$ : Short-term parameter

$\beta_{11}-\beta_{18}$ : Long-term parameter

$\Delta \quad$ : first difference

$t \quad$ : time-series data

Statistically, the value of ECT-1 must be significant and negative. This means that when there is a short-term disequilibrium between the dependent variable and many independent variables, the model will return to long-term equilibrium.

\section{Methodology}

\section{ARCH / GARCH Method}

The Autoregressive Conditional Heteroscedasticity $(\mathrm{ARCH})$ model was first introduced by Engle (1982) and was used to explain the uncertainty of the inflation rate (Bollerslev, 1986). In its development, Engle (2001) developed the Autoregressive Conditional Heteroscedasticity $(\mathrm{ARCH})$ model to test the volatility of financial series. This variable residual 
variant occurs because the residual variant is not only a function of the independent variable but depends on how large the residual is in the past. Simply put, the ARCH Model is based on a residual variant at a specific time, influenced by the residual period before.

The ARCH conditional variance (ht) model depends on past squared residuals, as in the equation below:

$$
h_{t}=\alpha_{0}+\sum_{i=1}^{q} \alpha_{i} \varepsilon_{t-i}^{2}
$$

The above model has the assumption of conditional variance (ht) depending on the residual squared of the past. The model states that the variance of the error term et, namely ht, has two components: constant (a0) and error term last period (lag), which is assumed to be the square of the error term of the previous period. The model of et is heteroscedastic conditional on residual et-1.

In the empirical application of the ARCH model, relatively long lags in the conditional variance equation are often needed, and to avoid problems with the estimation of negative variance parameters. A fixed lag structure is usually imposed (Engle, 2001). In this case, it seems to attract practical interest to expand the ARCH model class to allow for more extended memory and flexible lag structures. Bollerslev (1986) then developed ARCH to be more practical and flexible, by making ht as a function of the lag value of ht itself and the lag value of et2, following the GARCH model:

$$
h_{t}=\alpha_{0}+\sum_{i=1}^{q} \alpha_{i} \varepsilon_{t-i}^{2}+\sum_{i=1}^{p} \beta_{i} h_{t-i}
$$

The GARCH model explains that the residual variant does not only depend on the previous residual, but also the previous residual variant. The above GARCH provisions are $\alpha$ $0>0$, so there is no negative conditional variance ( $h t>0)$.

\section{Autoregressive Distributed Lag (ARDL) Method}

Autoregressive Distributed Lag (ARDL) is often used by researchers in analyzing the short-term and long-term relationships between dependent variables and independent variables of research. Regression models include variable values that explain the bound variable's present and past values as one of the explanatory variables called Autoregressive Distributed Lag (Gujarati, 2016). Before ARDL was developed by Pesar (2001), the cointegration method from Engle and Granger (1987) and Johansen and Juselius (1990) were often used, each of these methods had limitations in applying the level of integration in research (Evans, 2013). Furthermore, Pesar et al. (2001) developed the Autoregressive Distributed Lag (ARDL) cointegration model to handle variables with mixed integration levels, namely at levels I (0) and I (1). Besides, the ARDL model also utilizes the lag of variables, which makes the model more dynamic.

ARDL approach to testing the long-term relationship between variables has several advantages among other cointegration methods. This method is entirely secure with other cointegration methods because it can use the OLS regression model. Another advantage is that ARDL testing can test at the stationary level I (0) and I (1), and the ARDL method is more efficient for small samples. The basic ARDL model in this study is based on the Error Correction Model (ECM) framework that considers long-term balance with short-term adjustments. 


\section{Result and Discussion Unit Root Test}

The first step is to look at the stationarity test to determine at what degree the data will be stationary. In the ARDL model, it does not matter stationary data at the same level that is at the level I (0) or I (1), as long as it does not reach I (2). This study tested all variables using the Augmented Dickey-Fuller (ADF) method.

Table 2 shows that the exchange rate volatility (VOLEX) and fixed oil price (OPR) changes are at the level. Simultaneously, the COVID variable and the natural logarithm variable are national stock price (LSP). Based on the ADF value, each variable is stationary at I (1), and there are no stationary variables at level I (2), so it is feasible to use the ARDL model.

Table 2: ADF Unit Root Test

\begin{tabular}{lll} 
Variabel & Data tingkat level & Data First Difference \\
\hline VOLEX & $-0.120^{* *}$ & $-0.878^{* * *}$ \\
LSP & -0.029 & $-0.913^{* * *}$ \\
COVID & 0.029 & $-4.182^{* * *}$ \\
OPR & $-1.056^{* * *}$ & $-3.375^{* * *}$
\end{tabular}

Sumber: data diolah, ${ }^{*}$ signifikan pada $\alpha=0.10,{ }^{* *}$ signifikan pada $\alpha=0.05$, $* * *$ signifikan pada $\alpha=0.01$.

\section{Optimum Lag Test}

In getting the best ARDL model, the optimum lag length determination process is needed, one of which is using the Akaike Information Criteria in eviews 10 software. Based on the test results (Table 3 ) using the ARDL approach the model that has the smallest AIC value in model 1 is ARDL (Volex, LSP, COVID, OPR) $(2,0,3,0)$ and in model 2 is ARDL (Volex, BND, KAR, LAK, MYR, MYK, FIP, SGD, THB, VND) (4, 4, 4, 4, 3, 3, 4, 3, 2, 4).

Table 3. Result of ARDL Model Optimal Lag

\begin{tabular}{|c|c|c|c|c|c|}
\hline & & & & & \\
\hline \multicolumn{6}{|l|}{ Structure } \\
\hline $\log \mathrm{L}$ & & 703.44 & 707.33 & 704.28 & 704.22 \\
\hline AIC & & -16.73 & -16.73 & -16.73 & -16.73 \\
\hline \multirow[t]{2}{*}{ Adj. $R^{2}$} & & 0.82 & 0.83 & 0.82 & 0.82 \\
\hline & & Model 2 & & & \\
\hline $\begin{array}{l}\text { Optimal } \\
\text { Structure }\end{array}$ & Lag & $\begin{array}{l}(4,4,4,4,3,3,4 \\
2,2,4)\end{array}$ & $\begin{array}{l}(4,4,4,4,3,3,4, \\
3,2,4)\end{array}$ & $\begin{array}{l}(4,4,4,2,0,1,4 \\
1,0,0)\end{array}$ & $\begin{array}{l}(4,4,4,4,3,3,4, \\
2,3,4)\end{array}$ \\
\hline $\log L$ & & 758.74 & 759.46 & 744.37 & 759.27 \\
\hline AIC & & -17.04 & -17.03 & -17.03 & -17.03 \\
\hline $\operatorname{Adj} . R^{2}$ & & 0.89 & 0.89 & 0.88 & 0.89 \\
\hline
\end{tabular}

\section{Cointegration Test}

A cointegration test is used to determine the long-term relationship between the independent and dependent variables by looking at the value of trace statistics on the test results. According to the estimation results in Table 4, two equations have a trace statistic value higher than the critical value with a significance of $5 \%$. This explains that there is a longterm relationship between the independent variable and the dependent variable in the study. 


\section{Table 4. Johansen Cointegration Test}

Model 1

\begin{tabular}{lll} 
Hypothesized & Trace Statistic & Critical value 0.05 \\
\hline$r=0^{*}$ & 78.74 & 47.86 \\
$r<1^{*}$ & 35.06 & 29.80 \\
$r<2$ & 7.29 & 15.49 \\
$r<3$ & 1.77 & 3.84 \\
\hline Model 2 & \\
Hypothesized & Trace Statistic & Critical value 0.05 \\
\hline$r=0^{*}$ & 308.19 & 239.23 \\
$r<1^{*}$ & 235.92 & 197.37 \\
$r<2^{*}$ & 170.71 & 159.53 \\
$r<3^{*}$ & 126.60 & 125.61 \\
\hline
\end{tabular}

\section{Results Analysis}

\section{IDR / USD Exchange Rate Volatility during Pandemic}

Figure 5 presents the plot of IDR / USD volatility during a pandemic, the daily volatility value of the IDR / USD exchange rate is obtained from the ARCH / GARCH equation which includes the residual value and residual variance of the previous period, to obtain the results of the volatility of the conditional variance, as shown in Figure 5 . Figure 5 shows that the IDR / USD exchange rate for the end of January (M1) tends to be stable in the range of Rp $13,600.00$ - Rp13,800.00. Volatility is quite high occurred in February (M2), precisely on February 28, 2020, the exchange rate touched Rp. 14,234.00 then depreciated sharply in March (M3), precisely March 23, 2020 (M3) to Rp. 16,608.00, throughout this period, recorded a flat average IDR / USD exchange rate change of $46 \%$. This condition was triggered by the first case of COVID-19 in Indonesia on March 2, 2020. It has increasingly spread to several parts of Indonesia, recorded during March around 200 people who have been infected with the infectious disease. Plus, on March 11, 2020, the contagious disease COVID-19 was announced as a global pandemic by WHO, resulting in some of these critical events, causing uncertainty in the global economy.

Not to mention, the Government of Indonesia has implemented work from home, physical distancing policies to Large Scale Social Restrictions in several regions, which then has an impact on slowing and even closing some economic activities in Indonesia. The above scenario has an impact on the high volatility of the Rupiah against the US Dollar seen in April (M4). The IDR / USD exchange rate fell sharply to Rp16,741.00 on April 2, 2020, recorded as the lowest depreciation in the last ten years. 


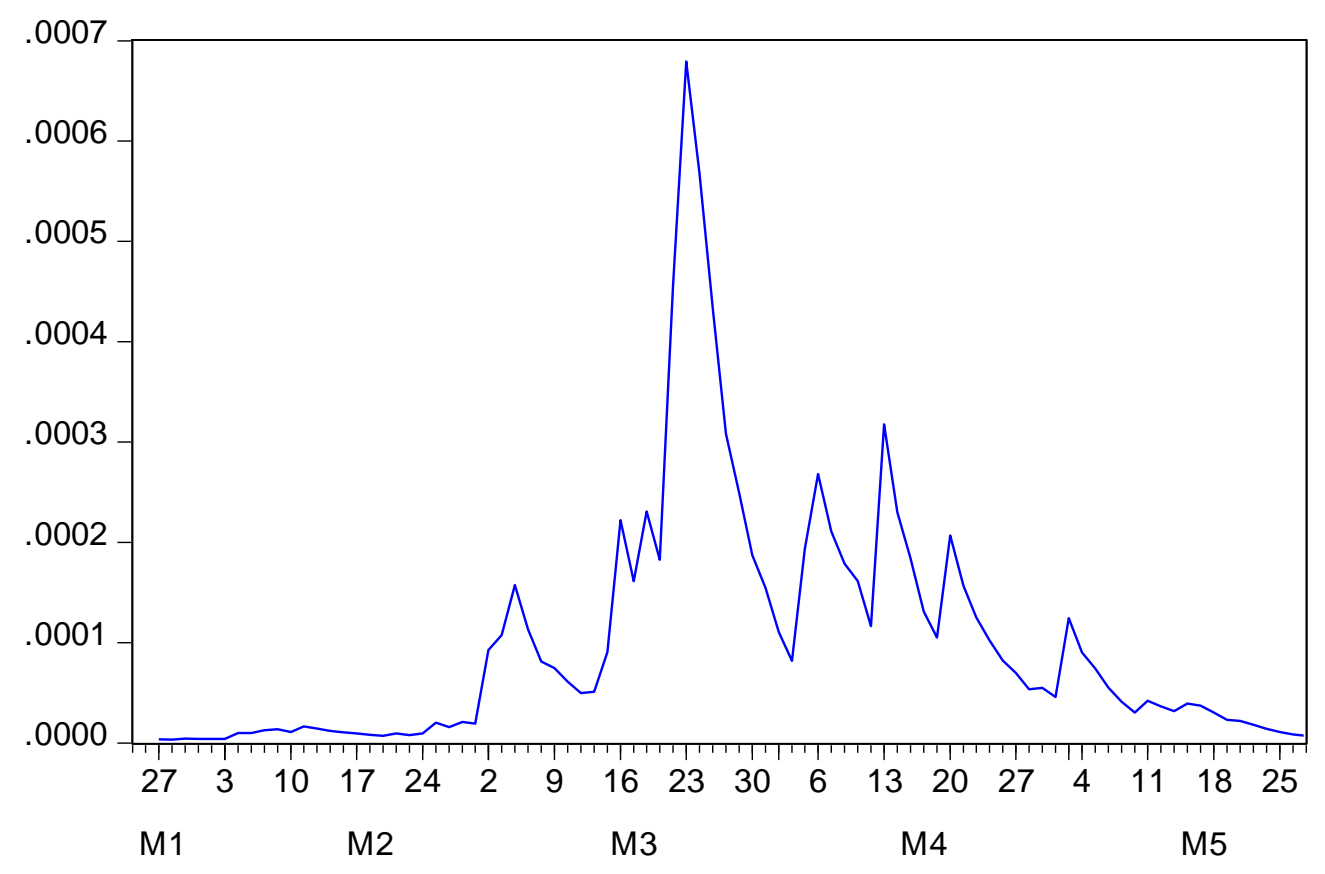

Source: Own elaboration.

\section{Figure 5. Pandemic's IDR / USD Volatility COVID-19}

Not to mention, the Government of Indonesia has implemented work from home, physical distancing policies to Large Scale Social Restrictions in several regions, which then has an impact on slowing and even closing some economic activities in Indonesia. The above scenario has an impact on the high volatility of the Rupiah against the US Dollar seen in April (M4). The IDR / USD exchange rate fell sharply to Rp16,741.00 on April 2, 2020, recorded as the lowest depreciation in the last ten years.

\section{Effects of National Stock Prices, COVID-19, and Changes in World Oil Prices on Exchange Rate Volatility in IDR / USD}

Table 5 displays the estimation results in the ARDL model $1(2,0,3,0)$. In the long run, all coefficients calculated are statistically significant in explaining the factors influencing volatility in exchange rates. Explanation per variable, the national stock price is significant at the level of 1\%, the total new cases of COVID-19 every day is significant at the level of $1 \%$, and changes in oil prices are significant at the level of $10 \%$ to the volatility of the IDR / USD exchange rate. The short-term estimation results show that the ECT value is significant at a $1 \%$ level and has a value of $-1,248$; the value is less than -1 , indicating oscillatory convergence. The results also show that the exchange rate volatility variable in the previous period, the COVID variable and the world oil price variable significantly influences exchange rate volatility in the short run, only the national stock price variable is not significant to the exchange rate volatility in the short term. Following the estimation results in the short term, the increase in the number of new COVID-19 cases has a systemic risk to the exchange rate volatility in Indonesia. This result is under several previous studies (e.g., Villarreal-Samaniego (2020), Albulescu (2020), Cardona-Arenas (2020). 
Table 5. Result of long-run and short-run coefficient the ARDL Model 2

ARDL Model $(2,0,3,0)$ selected based on AIC

\begin{tabular}{|c|c|c|c|c|}
\hline & Coefficient & SE & t-statistic & $p$-value \\
\hline \multicolumn{5}{|c|}{ Long-run estimation } \\
\hline LSP & $-0.000996 * * *$ & 0.000151 & -6.601563 & 0.0000 \\
\hline COVID & $-3.72 \mathrm{E}-07 * * *$ & 8.57E-08 & -4.343001 & 0.0000 \\
\hline OPR & $-7.61 \mathrm{E}-05^{*}$ & 4.26E-05 & -1.785905 & 0.0781 \\
\hline \multicolumn{5}{|c|}{ Short-run estimation } \\
\hline $\mathrm{D}(\operatorname{VOLEX}(-1))$ & $1.077401 * * *$ & 0.195754 & 5.503850 & 0.0000 \\
\hline $\mathrm{D}(\operatorname{VOLEX}(-2))$ & $-0.220156^{* *}$ & 0.102853 & -2.140482 & 0.0356 \\
\hline $\mathrm{D}(\mathrm{LSP})$ & -0.000178 & 0.000255 & -0.699703 & 0.4863 \\
\hline $\mathrm{D}(\mathrm{COVID})$ & $7.25 \mathrm{E}-08^{*}$ & $4.24 \mathrm{E}-08$ & 1.709486 & 0.0916 \\
\hline $\mathrm{D}(\operatorname{COVID}(-1))$ & $-6.91 E-08$ & 4.67E-08 & -1.478411 & 0.1435 \\
\hline $\mathrm{D}(\operatorname{COVID}(-2))$ & $-6.03 E-08$ & 4.29E-08 & -1.405892 & 0.1639 \\
\hline $\mathrm{D}(\operatorname{COVID}(-3))$ & $-5.94 \mathrm{E}-08$ & $3.58 \mathrm{E}-08$ & -1.660601 & 0.1010 \\
\hline $\mathrm{D}(\mathrm{OPR})$ & $-3.54 \mathrm{E}-05^{* * *}$ & $1.25 \mathrm{E}-05$ & -2.831630 & 0.0060 \\
\hline C & $1.96 \mathrm{E}-07$ & $5.83 \mathrm{E}-06$ & 0.033574 & 0.9733 \\
\hline ECT & $-1.248019 * * *$ & 0.235031 & -5.310008 & 0.0000 \\
\hline \multicolumn{5}{|c|}{ Residual Diagnostic Test } \\
\hline $\mathrm{R}^{2}$ & 0.841767 & & & \\
\hline Adj. $R^{2}$ & 0.825111 & & & \\
\hline $\begin{array}{l}\text { Serial } \\
\text { Correlation }\end{array}$ & 0.1669 & & & \\
\hline
\end{tabular}

* significant at $\alpha=0.10,{ }^{* *}$ significant at $\alpha=0.05, * * *$ significant at $\alpha=0.01$

\section{Effect of Exchange Rates of ASEAN Countries on Exchange Rate Volatility in IDR / USD}

Table 6 presents the ARDL model 2 estimation results, which considers the exchange rates of ASEAN countries as a result of the systemic risk due to the Pandemic. The results show that in the long run, the KAR / USD, MYK / USD, FIP / USD, and VND / USD exchange rates are not associated with IDR / USD exchange rate volatility at the $10 \%$ significance level. Different results are shown by the exchange rates of BND / USD, LAK / USD, MYR / USD, SGD / USD and THB / USD which significantly influence the volatility of the IDR / USD exchange rate.

In the short term, most of the ASEAN countries' exchange rates affected IDR / USD exchange rate volatility during the Pandemic, only the FIP / USD exchange rate was not related to IDR / USD exchange rate volatility. Estimation results show a different correlation between the exchange rates of countries in ASEAN with IDR / USD exchange rate volatility. This is related to the relationship in the economic sector of each country in ASEAN with the Indonesian economy. On the other hand, the ECT value has a value of -0.534 , where the value is significant at the level of $1 \%$ and has a negative value. This means that in the long run, the study's variables will adjust to balance with the speed of 53\% every day. The considerable R2 value (78\%) shows that the exchange rates of countries in ASEAN together can explain $78 \%$ of the exchange rate volatility during the observation period. The estimation results in model 2 confirm that the volatility of the IDR / USD exchange rate is influenced by the development of the financial markets of countries in ASEAN. 
Table 6. Result of long-run and short-run coefficient the ARDL Model 2

ARDL Model (4, 4, 4, 4, 3, 3, 4, 3, 2, 4) selected based on AIC

\begin{tabular}{|c|c|c|c|c|}
\hline & Coefficient & SE & t-statistic & $p$-value \\
\hline \multicolumn{5}{|c|}{ Long-run estimation } \\
\hline LBND & $0.020516^{* *}$ & 0.009956 & 2.060560 & 0.0457 \\
\hline LKAR & 0.005624 & 0.006269 & 0.897104 & 0.3749 \\
\hline LLAK & -0.011274 & 0.009471 & -1.190354 & 0.2408 \\
\hline LMYR & 0.000785 & 0.003392 & 0.231313 & 0.8182 \\
\hline LMYK & 0.000390 & 0.001304 & 0.299251 & 0.7663 \\
\hline LFIP & $0.010369 * *$ & 0.005102 & 2.032187 & 0.0486 \\
\hline LSGD & $-0.020320 * *$ & 0.00988 & -2.055486 & 0.0462 \\
\hline LTHB & $0.006181^{*}$ & 0.003499 & 1.766273 & 0.0848 \\
\hline LVND & -0.001024 & 0.007657 & -0.133692 & 0.8943 \\
\hline \multicolumn{5}{|c|}{ Short-run estimation } \\
\hline $\mathrm{D}(\operatorname{VOLEX}(-1))$ & 0.095311 & 0.093930 & 1.014702 & 0.3162 \\
\hline $\mathrm{D}(\operatorname{VOLEX}(-2))$ & -0.043240 & 0.095854 & -0.451101 & 0.6543 \\
\hline $\mathrm{D}(\operatorname{VOLEX}(-3))$ & $-0.304104^{* * *}$ & 0.098427 & -3.089638 & 0.0036 \\
\hline $\mathrm{D}($ LBND) & 0.002335 & 0.001526 & 1.529725 & 0.1338 \\
\hline $\mathrm{D}(\operatorname{LBND}(-1))$ & -0.002325 & 0.001980 & -1.174573 & 0.2469 \\
\hline $\mathrm{D}($ LBND(-2)) & 0.000961 & 0.001459 & 0.658627 & 0.5138 \\
\hline D(LBND(-3)) & $0.005810 * * *$ & 0.001220 & 4.761132 & 0.0000 \\
\hline $\mathrm{D}(\mathrm{LKAR})$ & 0.000302 & 0.001484 & 0.203426 & 0.8398 \\
\hline $\mathrm{D}(\operatorname{LKAR}(-1))$ & -0.000897 & 0.001533 & -0.585414 & 0.5615 \\
\hline $\mathrm{D}(\operatorname{LKAR}(-2))$ & $-0.004928 * * *$ & 0.001483 & -3.324297 & 0.0019 \\
\hline $\mathrm{D}(\operatorname{LKAR}(-3))$ & $-0.006038 * * *$ & 0.001470 & -4.108080 & 0.0002 \\
\hline $\mathrm{D}($ LLAK) & 0.001809 & 0.002872 & 0.629837 & 0.5323 \\
\hline $\mathrm{D}(\operatorname{LLAK}(-1))$ & 0.004098 & 0.003110 & 1.317707 & 0.1949 \\
\hline $\mathrm{D}(\operatorname{LLAK}(-2))$ & $0.008473 * * *$ & 0.002793 & 3.034014 & 0.0042 \\
\hline $\mathrm{D}(\operatorname{LLAK}(-3))$ & $0.005406 * *$ & 0.002241 & 2.412628 & 0.0204 \\
\hline$D(L M Y R)$ & -0.000126 & 0.001567 & -0.080106 & 0.9365 \\
\hline D(LMYR(-1)) & -0.000682 & 0.001495 & -0.456292 & 0.6506 \\
\hline $\mathrm{D}(\operatorname{LMYR}(-2))$ & $0.004397 * * *$ & 0.001570 & 2.800251 & 0.0078 \\
\hline$D($ LMYK) & $-0.002362 * * *$ & 0.000631 & -3.743564 & 0.0006 \\
\hline D(LMYK(-1)) & $-0.001575^{* *}$ & 0.000689 & -2.288259 & 0.0273 \\
\hline D(LMYK(-2)) & -0.001069 & 0.000671 & -1.593483 & 0.1187 \\
\hline$D($ LFIP) & $0.003902^{*}$ & 0.002208 & 1.767028 & 0.0847 \\
\hline $\mathrm{D}(\mathrm{LFIP}(-1))$ & -0.001931 & 0.002087 & -0.925260 & 0.3602 \\
\hline $\mathrm{D}(\mathrm{LFIP}(-2))$ & -0.003210 & 0.002046 & -1.568570 & 0.1244 \\
\hline $\mathrm{D}(\mathrm{LFIP}(-3))$ & $-0.005623 * * *$ & 0.001990 & -2.825144 & 0.0073 \\
\hline $\mathrm{D}(\mathrm{LSGD})$ & -0.001216 & 0.001783 & -0.682093 & 0.4990 \\
\hline $\mathrm{D}(\operatorname{LSGD}(-1))$ & $0.003465^{* *}$ & 0.001695 & 2.043928 & 0.0474 \\
\hline $\mathrm{D}(\mathrm{LTHB})$ & 0.000713 & 0.001661 & 0.428949 & 0.6702 \\
\hline $\mathrm{D}(\mathrm{LTHB}(-1))$ & $-0.004203 * *$ & 0.001672 & -2.513580 & 0.0160 \\
\hline $\mathrm{D}($ LVND) & -0.000907 & 0.002516 & -0.360379 & 0.7204 \\
\hline $\mathrm{D}(\operatorname{LVND}(-1))$ & -0.002693 & 0.002623 & -1.026583 & 0.3106 \\
\hline $\mathrm{D}(\operatorname{LVND}(-2))$ & $-0.009694 * * *$ & 0.002616 & -3.704859 & 0.0006 \\
\hline $\mathrm{D}(\operatorname{LVND}(-3))$ & $-0.003292 *$ & 0.001896 & -1.735816 & 0.0901 \\
\hline
\end{tabular}



$\mathrm{ECT}(-1)$
$-0.419805^{* * *}$
0.071496
$-5.871720$
0.0000

Residual Diagnostic Test

$\mathrm{R}^{2}$

0.947126

Adj. $R^{2}$

0.892963

Durbin-Watson

stat

2.098943

Serial

Correlation

0.5863

$\mathrm{ARCH}$

0.3876

* significant at $\alpha=0.10,{ }^{* *}$ significant at $\alpha=0.05, * * *$ significant at $\alpha=0.01$

Stability testing such as CUSUM and CUSUM-square is performed to investigate the stability of parameters in the long term, and short term uses. In Figure 6, the CUSUM Test and the CUSUM Square Test show that the plot for the two stability tests, in general, is between a critical limit at a significance of $5 \%$. This confirms the accuracy of short-term and long-term parameters that affect IDR / USD exchange rate volatility during the observation period.

Figure 6. CUSUM Test Plot and CUSUM Square Test
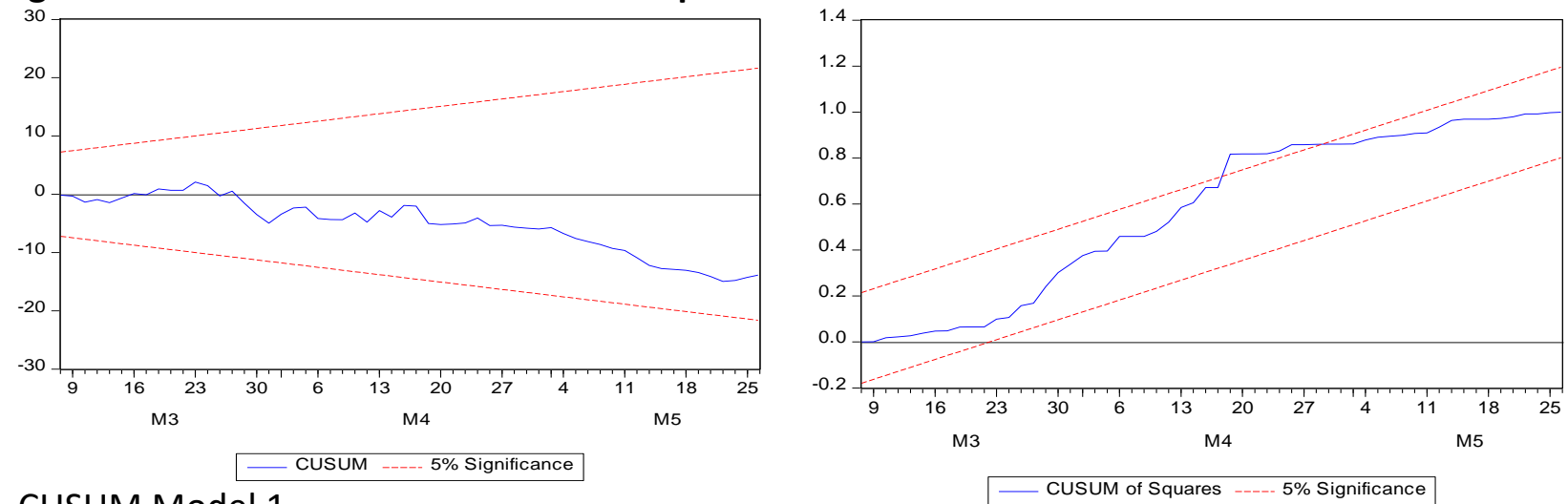

CUSUM Model 1

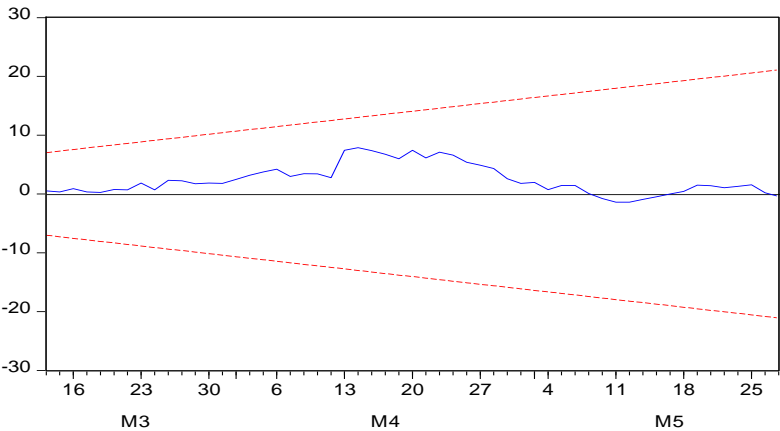

CUSUM Model 2

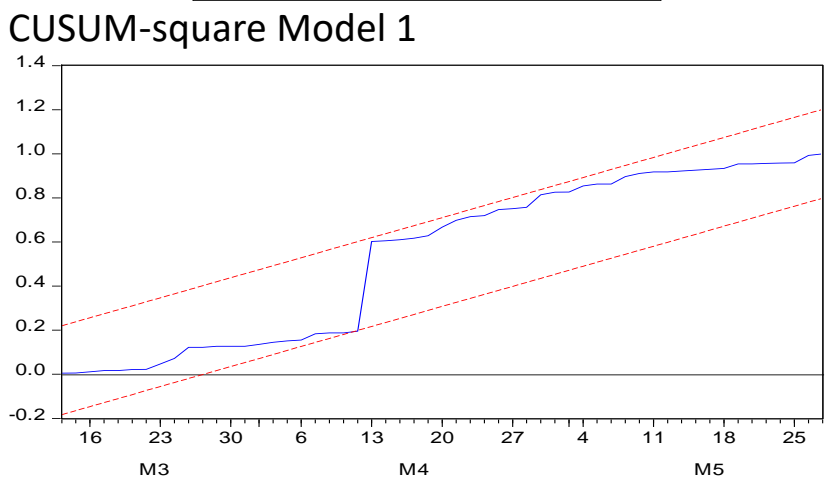

__ CUSUM of Squares _-_-_ $5 \%$ Significance

CUSUM-square Model 2

\section{Conclusions and Policy Recommendations}

This study examines the short-term and long-term relationship between COVID-19 variables, national stock prices, world oil prices and the exchange rates of ASEAN countries with IDR / USD exchange rate volatility during a pandemic, starting from January 23, 2020 May 27, 2020, by using the ARDL method introduced by Pesaran et al. (2001). The estimation results of the ARDL 1 model show that national stock price variables have significant and 
adverse effects on exchange rate volatility in the long run, but do not have a significant effect in the short term. The COVID-19 variable has a significant and negative effect on exchange rate volatility in the long run. In the short term, COVID-19 has a significant and positive effect on exchange rate volatility. This can be seen from the first case of COVID-19 confirmed on March 2, 2020, in Indonesia, the volatility of the financial sector emerged in line with the decline in market confidence and the occurrence of flight to quality in the financial sector.

World oil price variables based on estimation results have significant and adverse effects on exchange rate volatility in the long term, confirming that global shocks represented by changes in world oil prices have a systemic effect on exchange rate volatility in Indonesia. The relationship between exchange rate volatility and world oil prices is not only related to company costs and profits. However, it is also related to the achievement of targets for macroeconomic fundamentals, such as revenue targets planned by a country from the oil and gas sub-sector. However, Indonesia is still recorded as a world oil exporter to several countries, although the portion of imports is still more significant. Meanwhile, the estimation results of the ARDL 2 model show that the overall movement of the exchange rates of countries in ASEAN affects exchange rate volatility in the short term. In contrast, in the long run, only the exchange rates of BND / USD, FIP / USD, SGD / USD and THB / USD are affected by exchange rate volatility.

Based on research conclusions, that the COVID variable has significant and positive short-term and adverse long-term effects on exchange rate volatility so that monetary intervention and coordination with $\mathrm{G} 20$ countries are needed to reduce excessive currency changes, as an effort to mitigate exchange rate volatility during the COVID-19 Pandemic. Besides, the Government also needs to coordinate and deal with the $\mathrm{G} 20$ countries to reduce exchange rate volatility by limiting currency trade between countries. Also, it is essential to extend the duration of monetary interventions that have been carried out by Bank Indonesia and the Financial Services Authority, such as halt trading, interest rate interventions, and debt relief during the unfinished Pandemic. Thus, more extensive research is needed on exchange rate volatility caused by COVID-19, and other factors that have been volatile during the Pandemic. In the related literature, there are still other classifications in explaining COVID-19 variables, such as death rates, cure rates, and total case accumulations per day (VillarrealSamaniego, 2020; Cardona-Arenas, 2020; Albelescu, 2020). Therefore, research on modeling study to forecast the impact of COVID-19 on exchange rates and other macro variables can be conducted in the future and also use an event study approach to capture in detail the market reaction during the COVID-19 Pandemic.

\section{Acknowledgement}

This research publication fees is sponsored by RMI, UiTM Melaka

\section{References}

Handoyo, R. D., Ilyas, S. M., Ridzuan, A. R., Azhar, N. A. Z. M., \& Shaari, M. S. (2021). Towards Achieving Sustainability in Financial Market: The Impact of Covid-19, Oil Price, Stock Price on Exchange Rate Volatility in Indonesia. International Journal of Academic Research in Business and Social Sciences, 11(5), 842-863. 
INTERNATIONAL JOURNAL OF ACADEMIC RESEARCH IN BUSINESS AND SOCIAL SCIENCES Vol. 11, No. 5, 2021, E-ISSN: 2222-6990 @ 2021 HRMARS 